\title{
Morphoanatomy of the underground system of Androtrichum trigynum (Cyperaceae)
}

\author{
Morfoanatomia do sistema subterrâneo de Androtrichum trigynum (Cyperaceae)
}

Roberta Andressa Pereira ${ }^{1}$ \& Ana Claudia Rodrigues ${ }^{2,3}$

\begin{abstract}
Androtrichum has only one species, A. trigynum (Spr.) Pfeiffer, occurring in coastal regions of the southwestern Atlantic coast. It presents an underground system consisting of rhizomes and adventitious roots. The rhizome is thickened, plagiotropic, sympodial, and floral scapes and roots arise from it. From the stem promeristem, the protoderm, procambium and ground meristem are differentiated. At the apex region, the intercalary meristem and primary thickening meristem (PTM) are observed. The adventitious roots originate from the PTM, and present root apex with closed organization. The young epidermis has papillose cells, and meristematic endoderm activity is observed. In a mature root, the outer cortex, or hypodermis, and the internal cortex can be identified. The endoderm presents radially elongated cells with thin walls and the pericycle is biseriate. The anatomical features observed in the present study are found in other species of Cyperaceae and some xeromorphic characters can be identified.

Key-words: xeromorphic features, adventitious roots, rhizomes.

\section{Resumo}

Androtrichum apresenta uma única espécie, A. trigynum (Spr.) Pfeiffer, ocorrendo em regiões litorâneas da costa sudoeste atlântica. Apresenta o sistema subterrâneo constituído por rizomas e raízes adventícias. O rizoma é espessado, plagiotrópico e simpodial, do qual partem os escapos florais e as raízes. A partir do promeristema caulinar diferenciam-se a protoderme, o procâmbio e o meristema fundamental. Na região apical observam-se os meristemas intercalar e de espessamento primário (MEP). As raízes adventícias se originam do MEP e apresentam o ápice radicular do tipo fechado. A epiderme jovem apresenta células papilosas. Observa-se também a endoderme meristemática em atividade. Na maturidade, identifica-se o córtex externo ou hipoderme e córtex interno diferenciado em aerênquima. A endoderme tem células alongadas no sentido radial com paredes finas e o periciclo é bisseriado. As características anatômicas observadas no presente estudo condizem com outras espécies de Cyperaceae, e caracteres xeromorfos podem ser identificados.
\end{abstract}

Palavras-chave: caracteres xeromorfos, raízes adventícias, rizoma.

\section{Introduction}

Androtrichum trigynum (Spr.) Pfeiffer is the only species of the genus Androtrichum, Cyperaceae (Alves et al. 2009). Popularly known as juncoda-praia (Cordazzo et al. 2006), its geographic distribution is restricted to the southwest Atlantic coast, occurring from Argentina to southern Brazil (Costa et al. 1988). It is considered to be a heath, halophyte plant, abundant on the dunes settled in dry and humid areas. According to Cordazzo et al. (2006) swamps and depressions, periodically flooded, constitute habitats of great complexity and biological diversity of the coastal dunes, and A. trigynum has great importance in ecological structuring of these habitats due to its dominance in these areas.

Metcalfe (1971) describes, in general, the anatomy of the vegetative organs of many Cyperaceae species, as well as Kukkonen (1967); Eiten (1969);

\footnotetext{
'Part of the first author's Master's thesis

${ }^{2}$ Universidade Federal de Santa Catarina, Depto. Botânica, 88040-900, Florianópolis, SC, Brasil

${ }^{3}$ Corresponding author: anclaro@ccb.ufsc.br
} 
Sharma \& Mehra (1972); Govindarajalu (1974); Wills (1987); Estelita (1993) and Prata et al. (2007); however, these authors focus on the anatomy of mature organs in their studies.

Few studies refer to the ontogeny of underground organs in Cyperaceae species: Kadej (1963) interprets the apical root meristem of Cyperus gracilis R. Br.; Wills et al. (1980) and Gifford \& Bayer (1995) deal with the underground system ontogeny of $C$. esculentus $\mathrm{L}$.; Wills \& Briscoe (1970) describe the development of the underground stems of C. rotundus L., and Rodrigues \& Estelita (2002, 2004, 2009) studied the activity of the primary and secondary thickening meristems in the stem system of many species of the family, and also the development of C. giganteus Vahl. roots.

According to Rudall (1991), monocots species show, near the stem apex, the primary thickening meristem (PTM), located at a pericyclic region. The PTM has been mentioned mostly for the families Cyperaceae, Araceae, Eriocaulaceae, and Juncaceae (Rudall 1991); however, there is still some controversy regarding the definition or origin of the PTM. For some authors, the PTM is the pericycle itself, or, in some species, the pericycle and the endoderm with meristematic activity (Menezes et al. 2005), or the PTM has a pericyclic origin (Martins \& Appezzato-daGlória 2006). In the Cyperaceae species studied by Rodrigues \& Estelita (2002, 2009), the PTM is a sole meristem originated near the stem apex, as also observed in other monocot species by DeManson (1979a, b), Rudall (1991) and Gifford \& Bayer (1995).

Regarding root ontogeny in general, studies related to meristematic activity of the endoderm (Williams 1947; Melo-de-Pinna \& Menezes 2002, 2003; Rodrigues \& Estelita 2004; Alonso \& Moraes-Dallaqua 2004 and Menezes et al. 2005); and to the development of the aerenchyma in the cortical region are especially noteworthy in the literature, by authors such as Beckel (1956); Heimsch (1960); Clarck \& Harris (1981); Seago \& Marsh (1989); Drew et al. (2000) and Seago et al. (1999a, 2000, 2005). These studies show that the inner cortex of the roots is originated by periclinal divisions of the meristematic endoderm, which may form aerenchyma at maturity. The aerenchyma can have a schizogenous origin, by dissolution of the middle lamella, or lysigenous, when the spaces are formed following the lysis of some cortical cells, or by both processes, as observed in Cyperus giganteus (Rodrigues \& Estelita 2004).

On the other hand, the structural adaptations that may occur in such organs by the action of the environment cannot be ignored (Fahn \& Cutler 1992). The coastal dunes (restingas) present a highly stressful environment, causing species to develop a number of morphological, anatomical, physiological and reproductive adaptations (Cordazzo et al. 2006). Thus, this study aims to describe the underground system of Androtrichum trigynum (Spr.) Pfeiffer, focusing on the principal phases of differentiation of the tissues and highlighting possible morphoanatomical adaptations to the environment.

\section{Materials and Methods}

Specimens of Androtrichum trigynum (Spr.) Pfeiffer (Cyperaceae) were collected from the restinga of Parque Municipal das Dunas da Lagoa da Conceição, Florianópolis, located on the eastern coast of Santa Catarina Island (Florianópolis, $\mathrm{SC}$ ), between the coordinates $27^{\circ} 38^{\prime} 20,7^{\prime}$ 'S; $48^{\circ} 27^{\prime} 69,1$ ' W.

According to Strahler's classification, the city of Florianópolis (SC) has a subtropical humid climate, categorized as sub-hot (CECCA 1996). According to Beltrame et al. (2006), the temperatures of the studied area vary between $15^{\circ} \mathrm{C}$ and $18^{\circ} \mathrm{C}$ in winter, and between $24^{\circ} \mathrm{C}$ and $30^{\circ} \mathrm{C}$ in summer. Precipitation is well distributed during the whole year (average rate of $1,521 \mathrm{~mm}$ ) (CECCA 1996), and relative humidity of the air has an annual average rate of $82 \%$ (Herrmann 1989).

Part of the collected material was deposited in the "FLOR" herbarium under the number 37,276.

Samples of roots and rhizomes, at different stages of development, were fixed in glutaraldehyde $2.5 \%$ in $0.1 \mathrm{M}, \mathrm{pH} 7.2$ sodium phosphate buffer (Feder \& O'Brien 1968) for 24 hours. Posteriorly, they were washed in the same buffer and preserved in ethanol $70 \%$. Permanent slides were made with material embedded in paraffin and hydroxyethylmethacrylate resin. For paraffin, apical parts of the material were dehydrated in increasing tertiary butanol series (Johansen 1940), pre-infiltrated in paraffin oil and butanol, infiltrated in pure paraffin in three stages in an incubator at $60^{\circ} \mathrm{C}$. For resin, 
the manufacturer's instructions were followed. The material immersed using both techniques was sectioned with a steel razor using a Leica RM2125 rotary microtome, 7 to $10 \mu \mathrm{m}$ thick. The sections in hystoresin were stained with toluidine blue (O'Brien et al. 1965), and the sections in paraffin were stained with astra blue and safranin (Bukatsch 1972).

Semi-permanent slides were made from handmade sections of the mature material, with the aid of a proper razor; stained with safranin and astra blue (Bukatsch 1972) and mounted with glycerinated gelatin (Kraus \& Arduin 1997). Histochemical tests were carried out on fixed material, using Lugol for starch (Johansen 1940), Sudan III for lipophilic substances (Sass 1951), ferric chloride for phenolic substances, acidified phloroglucinol for lignin and ruthenium red for mucilage (Johansen 1940). The photomicrographs were made using a Leica MPS 30 DMLS microscope with a built-in digital camera.

\section{Results}

Morphology

Androtrichum trigynum is aphyllous, with a perennial and photosynthetic floral scape. The underground system consists of rhizomes and adventitious roots (Fig. 1a). The rhizome is thickened, plagiotropic and sympodial, with small internodes, and covered by reddish-brown cataphylls; from the axils, side buds emerge. From the rhizome, arise the floral scapes whose base is also covered by reddish-brown cataphylls. Roots arise from the rhizome internodes. When young, they have a light coloration; when mature, a darkbrown coloration.

\section{Anatomy - rhizome}

In a longitudinal section from the stem apex, the promeristem can be observed surrounded by early cataphylls (Fig. 1b). The apical meristem has a tunic-body formation, the tunic consisting of two to three cell layers (Fig. 1c), and the body, of many cell layers. From the promeristem, the protoderm, the procambium and the fundamental meristem are distinguished (Fig. 1b). The intercalary meristem can also be seen at the apical region (Fig. 1b) consisting of, approximately, 15 cell layers with thin walls and arranged in a stratified way (Fig. 1d) and the formation of side buds of the same composition as the apical bud (Fig. 2a).
From approximately $720 \mu \mathrm{m}$ from the apex, the primary thickening meristem (PTM) starts its activity. It has a circular shape, delimiting the cortical region and the vascular cylinder (Fig. $2 b$ ), producing centripetally, through periclinal divisions, vascular strands and parenchymatous cells, and only parenchymatous cells centrifugally (Fig. 2c). The PTM also originates adventitious roots (Fig. 2d). The epidermis is uniseriate, and the cortex, initially, is homogeneous (Fig. 2d).

Following the development of the organ, the activity of the PTM gradually diminishes, and its endoderm and pericycle are distinguished (Fig. $3 a-b)$. The endoderm presents radially elongated cells with thin walls (Fig. 3b). The pericycle is uniseriate, with isodiametric cells and thickened walls (Fig. 3b). At the vascular cylinder, there are isodiametric, conspicuous parenchymatous cells, with thin walls and few intercellular spaces (Fig. $3 \mathrm{c}$ ). All of the vascular bundles are amphyvasal and present a sheath of cells with thickened walls (Fig. $3 c-d)$. The outer bundles are formed by the PTM (Fig. 2c, 3a-b), and the inner bundles are formed by the procambium (Fig. 3c-d).

At maturity, the inner cortex and the outer cortex are distinguished (Fig. 4a). The outer cortex, or hypodermis, consists of compact hexagonal parenchymatous cells with thin walls (Fig. 4a). The inner cortex is formed by smaller cells in relation to the external cortical cells. They are isodiametric and with small intercellular spaces (Fig. 4a). It can also be observed that the innermost cells of this cortex, including the endoderm cells, have thickened walls (Fig. 4b-c). Many idioblasts having phenolic compounds are found throughout the whole rhizome (Fig. 2d, 3c, 4b-d), and in a lesser amount at the outer cortex (Fig. 4a). Phenolic compounds can also be observed on the walls of the endoderm cells and of the innermost cortical cells (Fig. 4c-d). Starch grains occur at the inner cortex (Fig. 4a), as well as at the vascular cylinder (Fig. 4b).

\section{Anatomy - roots}

The adventitious roots arise from the rhizome starting from the PTM (Fig. 2d). At the root apex, the root cap originates from periclinal divisions of the calyptrogen, which consists of a group of cells with conspicuous nuclei, arranged in compressed layers. The promeristem, the protoderm, the procambium and the fundamental meristem are also observed (Fig. 5a-c). 


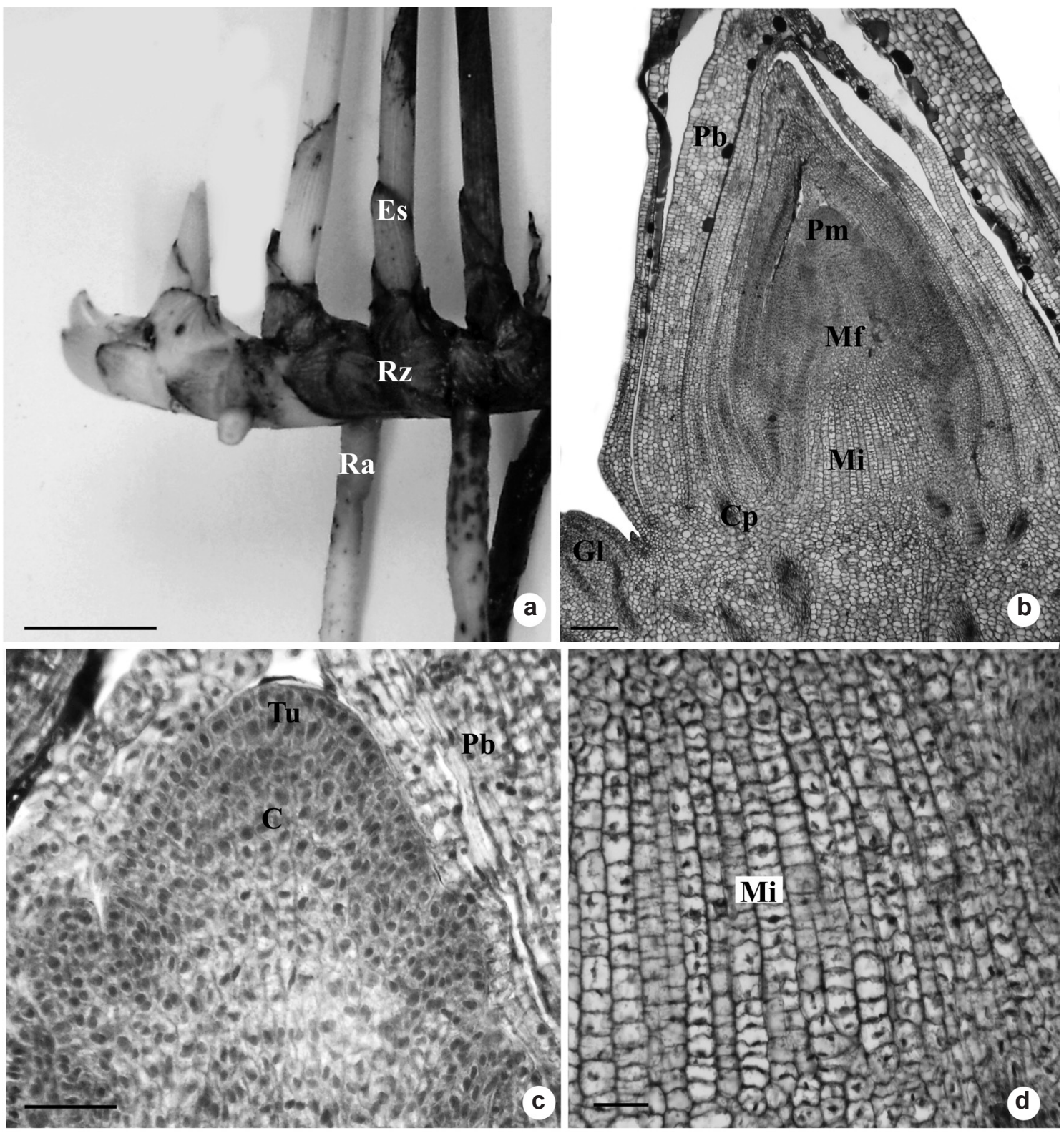

Figure 1 - Underground system of Androtrichum trigynum (Spr.) Pfeiffer. a. General aspect. b-d. Rhizome longitudinal sections. b. Stem apex. c. Detail of the previous figure showing promeristem organization. d. Detail of the intercalary meristem. $\mathrm{C}=$ corpus; $\mathrm{Cp}=$ procambial strand; $\mathrm{Es}=$ scape; $\mathrm{Gl}=$ lateral bud; $\mathrm{Mf}=$ ground meristem; $\mathrm{Mi}=$ intercalary meristem; $\mathrm{Pb}=$ bract primordium; $\mathrm{Pm}=$ promeristem; $\mathrm{Ra}=$ adventitious root; $\mathrm{Rz}=$ rhizome; $\mathrm{Tu}=$ tunica. $\mathrm{Bars}$ : 5 $\mathrm{cm}(\mathrm{a}), 100 \mu \mathrm{m}$ (b), $25 \mu \mathrm{m}$ (c-d).

From the promeristem, the initial cell common to the protoderm and the meristem is observed (Fig. 5b). The cylinder of procambium is easily observed, the promeristem region being very small (Fig. 5a-b). The protoderm cells gradually elongate radially as they drift away from the initial cell (Fig. 5c).
In transverse sections $120 \mu \mathrm{m}$ from the root apex, the cylinder of procambium, the beginning of meristematic activity of the endoderm and the root cap, still present, with many cell layers, is observed (Fig. 5d). The meristematic endoderm forms, through periclinal divisions, the radiated cortical region (Fig. 5d-e). 


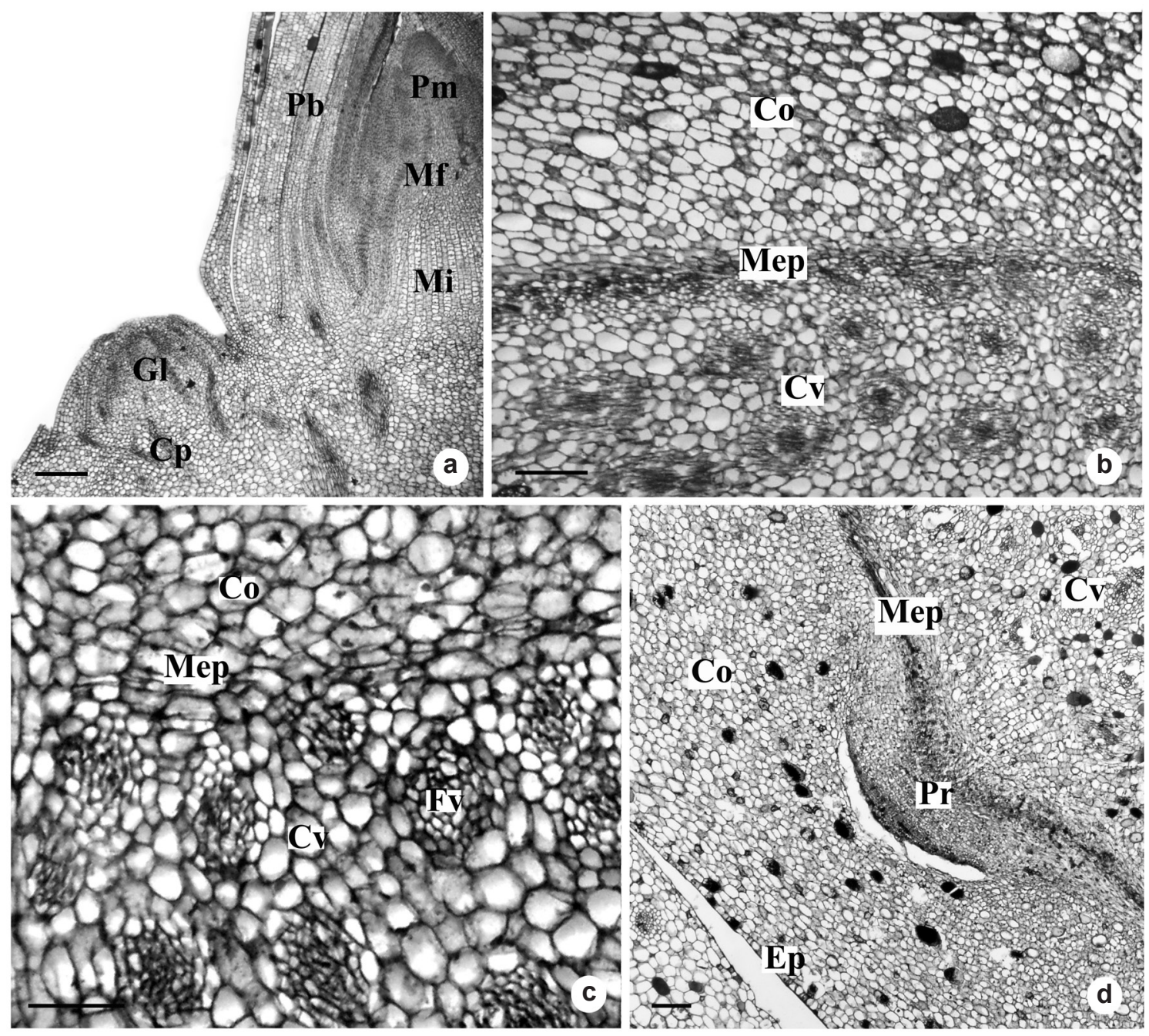

Figure 2 - Rhizome of Androtrichum trigynum (Spr.) Pfeiffer. Longitudinal section (a) and transverse sections (b-d). a. Shoot apex showing lateral bud. b. PTM arranged in circular shape between the cortex and vascular cylinder. c. Detail of the PTM. d. Origin of adventitious roots from the PTM. Co = cortex; $\mathrm{Cp}=$ procambial strand; $\mathrm{Cv}=\mathrm{vascular}$ cylinder; Ep = epidermis; Fv = vascular strand; Gl =lateral bud; Mep = primary thickening meristem; $\mathrm{Mf}=$ ground meristem; $\mathrm{Mi}=$ intercalary meristem; $\mathrm{Pb}=$ bract primordium; $\mathrm{Pm}=$ promeristem; $\mathrm{Pr}=$ root primordium $. \mathrm{Bars}: 100 \mu \mathrm{m}$.

On the sections $280 \mu \mathrm{m}$ from the root apex (Fig. 6a), we can observe 3 of 4 layers of root cap cells and the epidermis differentiated in papillose cells. Those have dense content and secrete a thick layer of substance, which is deposited between those cells and the root cap cells (Fig. 6b). The cortical region, at this stage of development, consists of outer cortex or hypodermis and inner cortex. The hypodermis (Fig. 6a, 6c) originates from the fundamental meristem and presents approximately six layers of isodiametric cells, with no intercellular spaces. The inner cortex
(Fig. 6a, 6d) results from periclinal divisions of the meristematic endoderm, showing about 22 cell layers radially disposed, with thin walls and conspicuous intercellular spaces (Fig. 6d). At the vascular cylinder, the vascular elements are in differentiation (Fig. 6a, 6d).

From $1610 \mu \mathrm{m}$ from the apex (Fig. 6e-g), the root cap cells disappear, and a considerable layer of substance secreted by the epidermal cells can still be observed, which present dense content as well as the outermost cells of the hypodermis (Fig. 6e-f). The meristematic endoderm ceases 


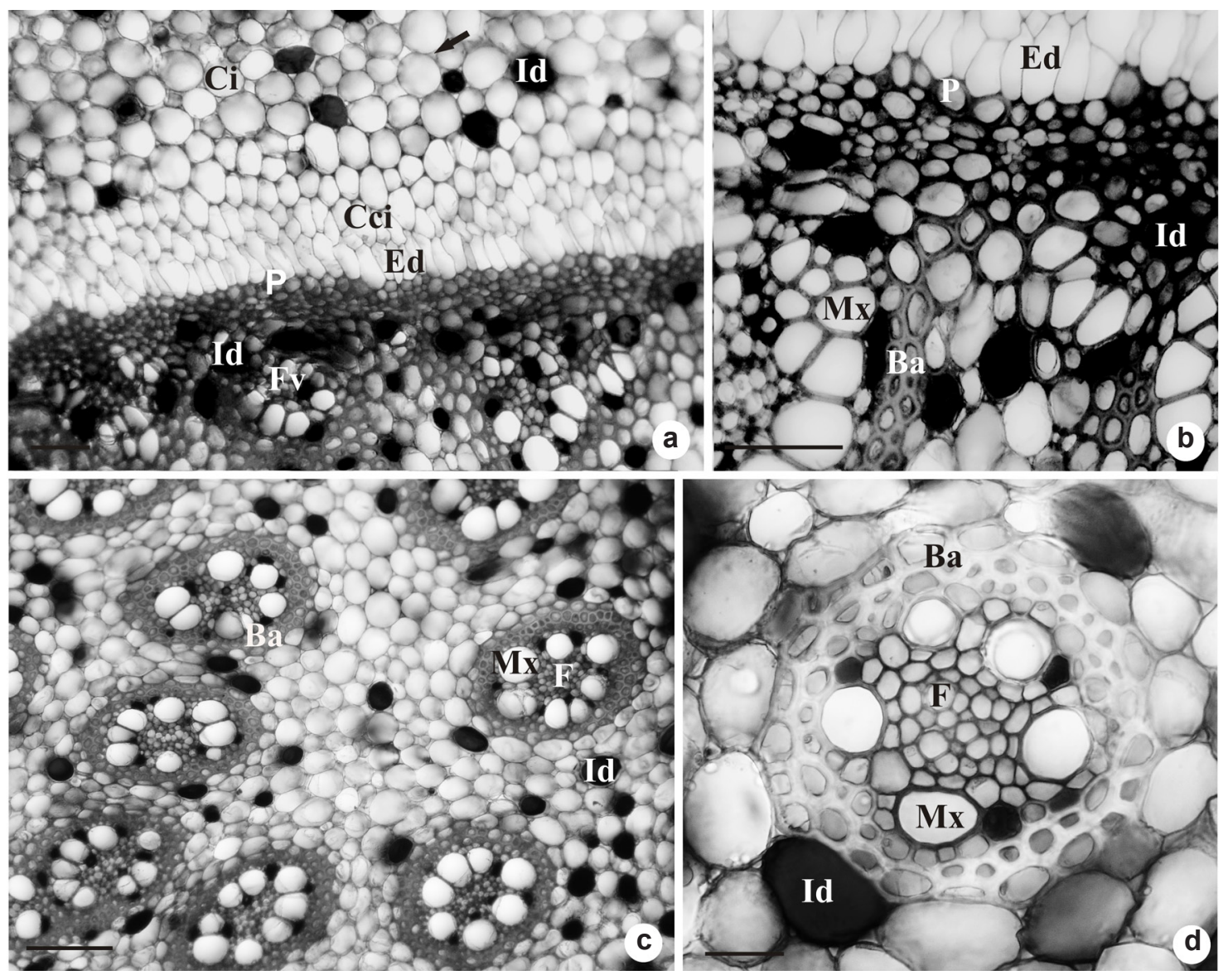

Figure 3 - Rhizome transverse sections of Androtrichum trigynum (Spr.) Pfeiffer. a. Endodermis and pericycle differentiated from PTM. b. Detail of the previous figure, showing the endodermis, pericycle and peripheral vascular bundles. c. Vascular bundles originated from the procambium. d. Detail of amphivasal vascular bundle. Ba=bundle sheath of thick-walled cells; $\mathrm{Ci}=$ inner cortex; $\mathrm{Ed}=$ endodermis; $\mathrm{F}=$ phloem; $\mathrm{Cci}=$ innermost cells of the inner cortex; Fv = vascular bundle; Id = idioblasts; $\mathrm{Mx}=$ metaxylem; $\mathrm{P}=$ pericycle. Bars: $100 \mu \mathrm{m}(\mathrm{c}), 50 \mu \mathrm{m}(\mathrm{a}-\mathrm{b}, \mathrm{d})$.

its activity and begins to differentiate in radially elongated cells (Fig. 6g). At the vascular cylinder, the biserial pericycle and the elements of xylem and phloem still in differentiation are observed (Fig. 6e, 6g). Idioblasts with phenolic compounds begin to appear at the inner cortex and at the pith (Fig. 6e).

On the transverse sections $2870 \mu \mathrm{m}$ from the apex (Fig. 7a), the thick layer of substance secreted by the epidermis becomes thin (Fig. $7 a-b)$. The intercellular spaces of the inner cortex become more conspicuous (Fig. 7c). The endoderm is now completely differentiated, which can be observed by the high level of vacuolation of the cells, as well as the pericycle and vascular elements (Fig. 7c).
At maturity, part of the inner cortex transforms into schizo-lysigenous aerenchyma (Fig. 7d), starting with the dissolution of the middle lamella increasing the intercellular spaces, which then become more evident with the lysis of the cells. The endoderm cells remain with thin walls, and the innermost cell layers of the cortex start to have their walls thickened (Fig. 7e). The root is polyarc, with a great number of metaxylem elements surrounding the pith region (Fig. 7e).

\section{Discussion}

The underground stem of Androtrichum trigynum is a rhizome, as it shows the morphological characteristics described by many authors to define this organ (Font Quer 1982; 

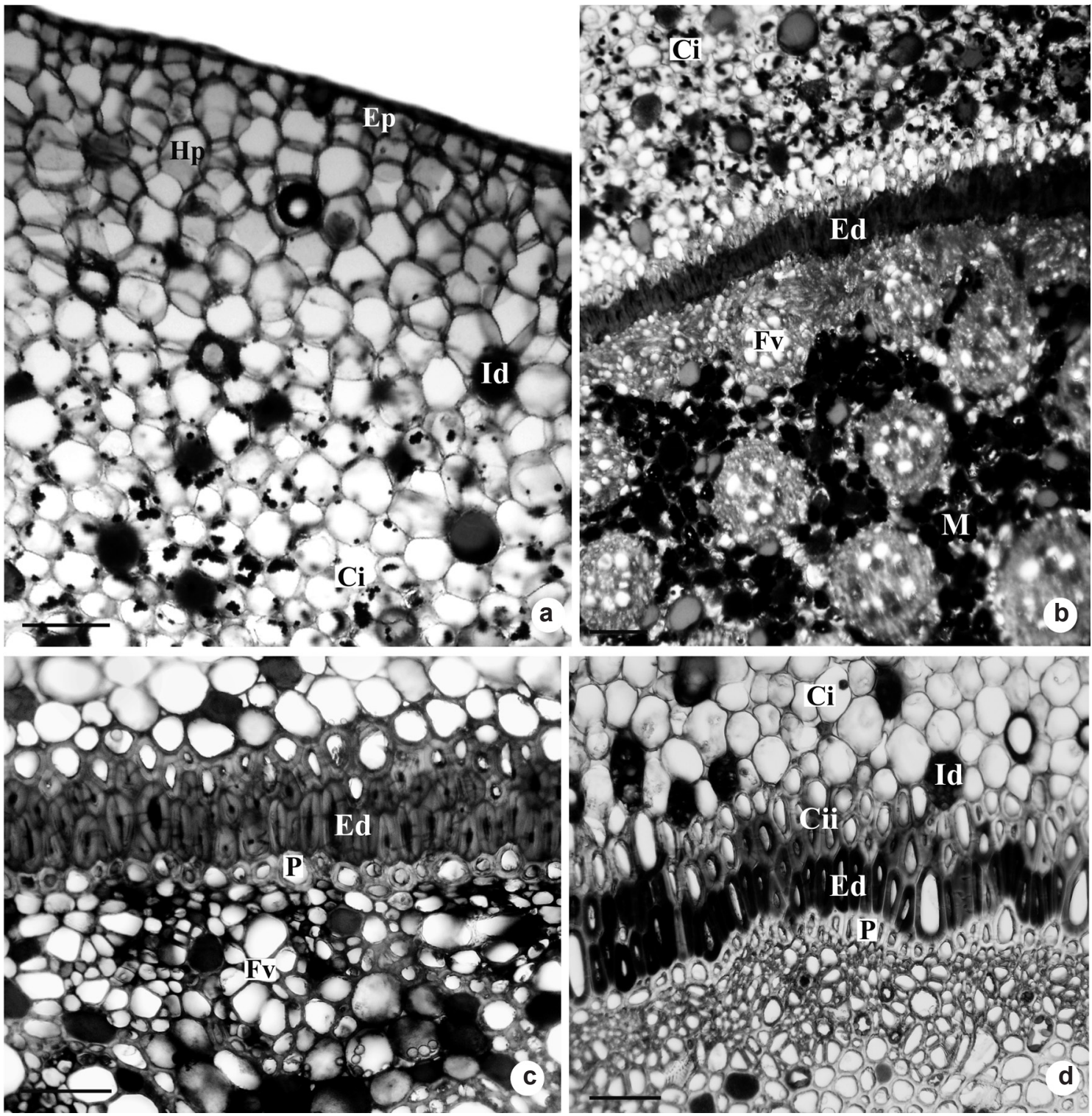

Figure 4 - Rhizome transverse sections of Androtrichum trigynum (Spr.) Pfeiffer. a. Hypodermis with no starch grains is observed. b. Parenchyma cells of the inner cortex and vascular cylinder with starch grains. c. Note the thickening of the innermost cortical cells and the endodermis and pericycle cells. d. Detail of the innermost cortical cells and the endodermis cells with phenolic compounds on their walls. $\mathrm{Cci}=$ innermost cells of the inner cortex; $\mathrm{Ci}=\mathrm{inner}$ cortex; $\mathrm{Ed}=$ endodermis; $\mathrm{Ep}=$ epidermis; $\mathrm{Fv}=$ vascular bundle; $\mathrm{Hp}=$ hypodermis; $\mathrm{Id}=$ idioblasts; $\mathrm{M}=$ pith; $\mathrm{P}=$ pericycle. Bars: $50 \mu \mathrm{m}(\mathrm{c}-\mathrm{d}), 100 \mu \mathrm{m}(\mathrm{a}-\mathrm{b})$.

Bell 1991; Appezzato-da-Glória 2003). The aerial stem, is spite of being perennial, is classified as reproductive, as it is the axis of the inflorescence or floral scape, as occurs in other Cyperaceae species described by Estelita \& Rodrigues (2007). According to these authors, the main anatomical characteristic that distinguishes the stem from the scape in Cyperaceae is the presence of the PTM in the former, as occurs in A. trigynum.

The anatomy of the stem and root apexes of A. trigynum is similar to what is described for the other Cyperaceae species (Gifford \& Bayer 1995; Rodrigues \& Estelita 2002, 2004 and 2009). It draws attention, however, to the papillose 

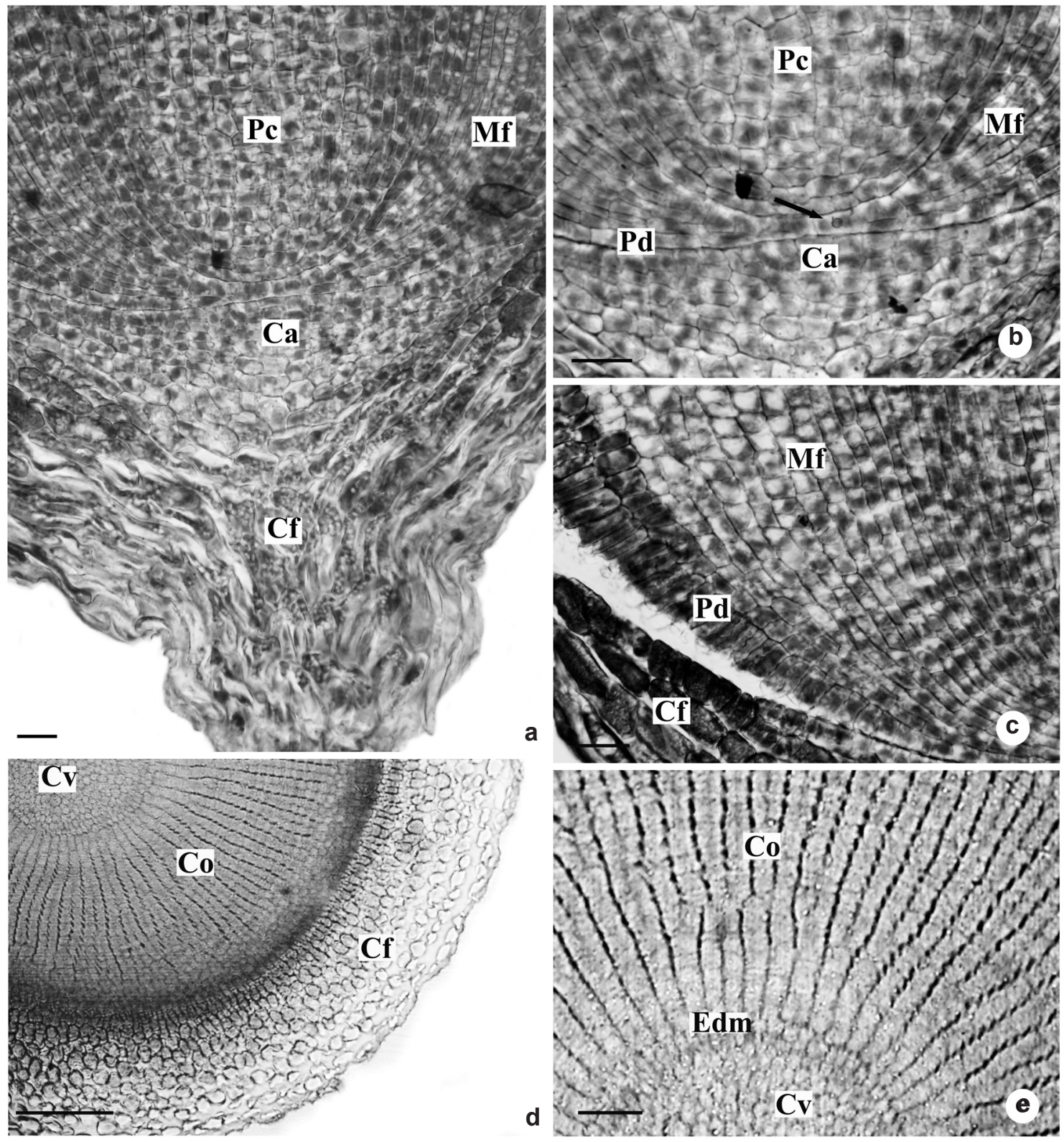

Figure 5 - Root apex of Androtrichum trigynum (Spr.) Pfeiffer. a-c. Longitudinal sections of root apical meristem. a. Organization of the apical meristem. b. Detail showing the initial cell (arrow) common to the ground meristem and protoderm. c. Detail showing the radial elongation of the protoderm cells. d-e. Transverse sections at $120 \mu \mathrm{m}$ from the root apex. d. Note the vascular cylinder and cortical region in differentiation. e. Detail of the previous figure, showing the meristematic activity of the endodermis forming the cortical cells. Ca - calyptrogen; Cf - root cap; $\mathrm{Co}$ - cortex; $\mathrm{Cv}$ - vascular cylinder; Edm - meristematic endodermis; Mf - ground meristem; Pc - procambium; Pd - protoderm. Bars: $25 \mu \mathrm{m}(\mathrm{a}-\mathrm{c}), 100 \mu \mathrm{m}(\mathrm{d}), 50 \mu \mathrm{m}(\mathrm{e})$.

epidermal cells of the root of $A$. trigynum, which do not form root hairs, but secrete mucilage, detected with an specific test. For Mauseth (1988), the mucilaginous substance secreted by the apical region of the roots is known as mucigel, which would protect and lubricate the root apex, aiding water and nutrient absorption (Dickison 2000). It is believed that, in A. trigynum, mucilage also works as a thermal insulator to the high temperatures that reach the soil, especially in winter, also helping on 

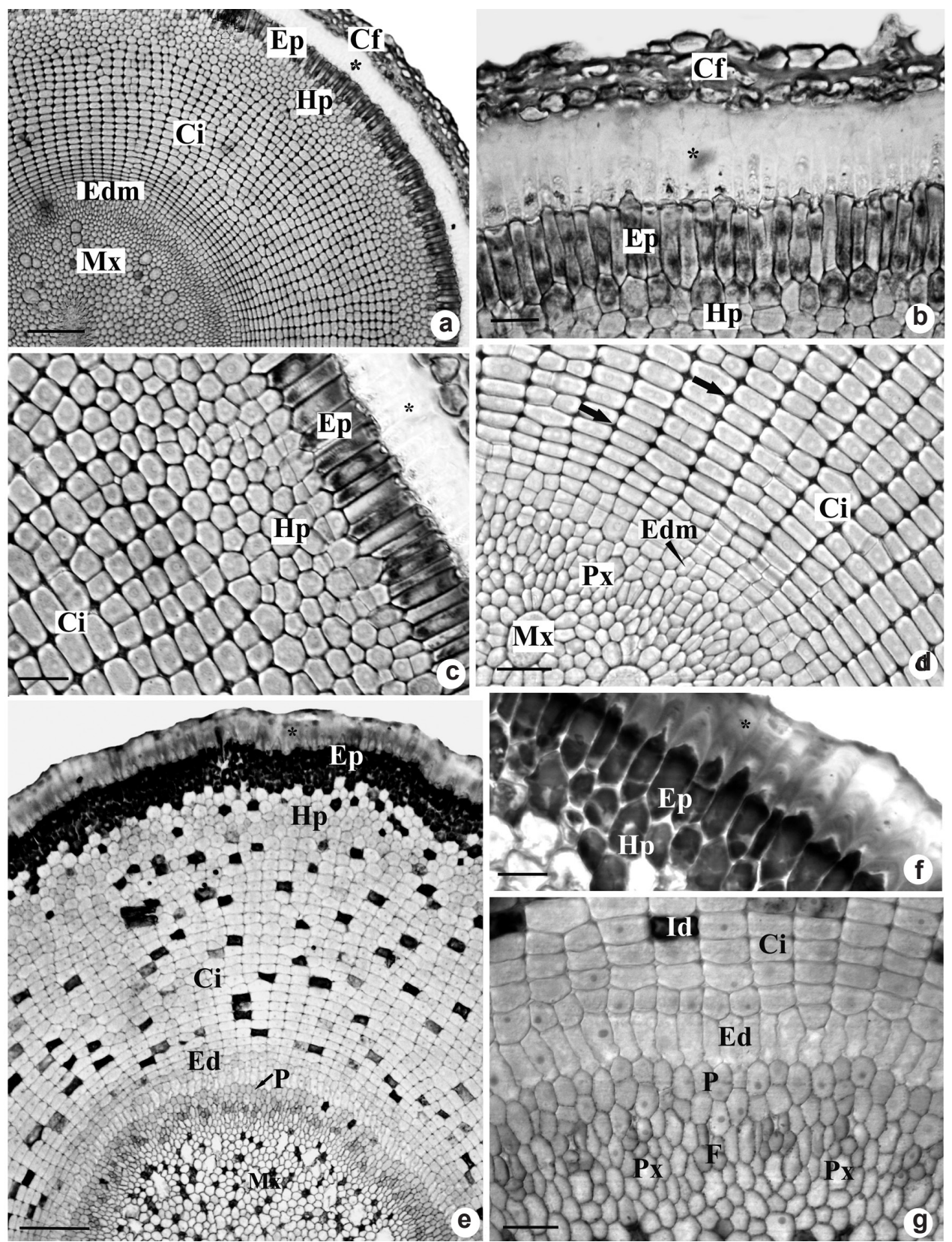

Figure 6 - Root apex transverse sections of Androtrichum trigynum (Spr.) Pfeiffer. a-d. Sections at $280 \mu \mathrm{m}$ from the root apex. a. General aspect. b. Detail of the substance secreted by epidermal cells $(*)$. c. Outer cortex or hypodermis and inner cortex. d. Inner cortex originated from the meristematic endodermis with schizogenous intercellular spaces (arrows) and vascular elements in differentiation in the vascular cylinder. e-g. Sections at $1610 \mu \mathrm{m}$ from the root apex. e. General aspect. f. Detail of the epidermal cells and outer cortex. g. Detail of the endodermis and vascular cylinder. Cf - root cap; $\mathrm{Ci}$ - inner cortex; Edm - meristematic endodermis; Ed endodermis; Ep - epidermis; F - phloem; Hp - hypodermis; Id - idioblasts; Mx - metaxylem; P - pericycle; Px - protoxylem. Bars: $100 \mu \mathrm{m}$ (a, e), $20 \mu \mathrm{m}$ (b-d, f-g). 


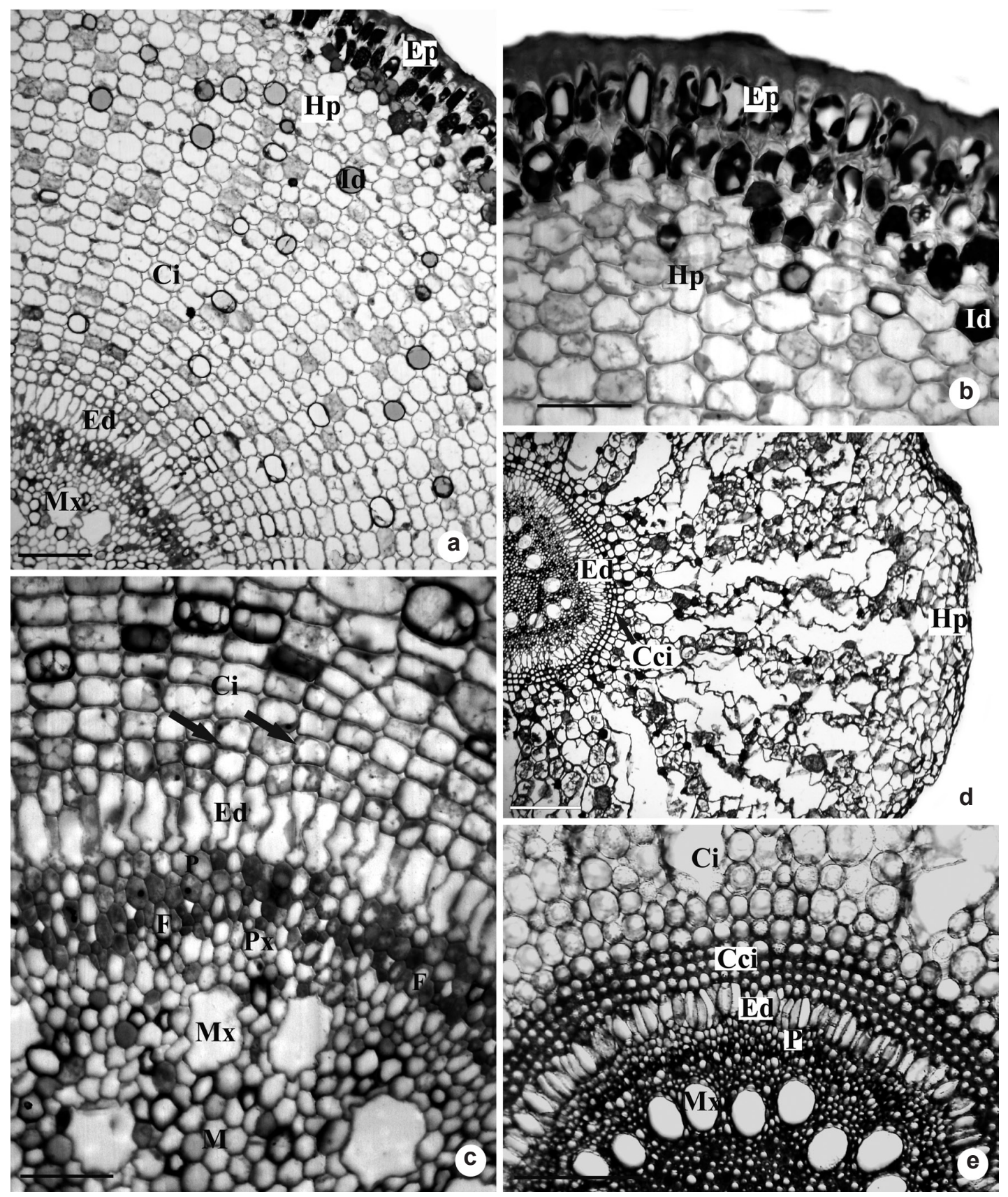

Figure 7 - Root transverse sections of Androtrichum trigynum (Spr.) Pfeiffer. a. General view. b. Detail of the epidermis and outer cortex. c. Thickening of the walls of the inner cortical cells (arrows). d. Later stage of development, showing schizo-lysigenous aerenchyma, endodermis (arrow) with thin-walled elongated cells and metaxylem elements differentiated. e. Mature root, showing detail of the cortex and vascular cylinder. Cci - innermost cells of the inner cortex; Ci - inner cortex; Ed - endodermis; Ep - epidermis; F - phloem; Hp hypodermis; Id - idioblasts with phenolic compounds; Mx - metaxylem; P - pericycle; Px - protoxylem. Bars: $100 \mu \mathrm{m}$ (a, d-e), $50 \mu \mathrm{m}$ (b), $20 \mu \mathrm{m}$ (c). 
water retention and thus preventing desiccation, as Dickison (2000) suggests.

The intercalary meristem (IM), observed at the stem apex of $A$. trigynum, was also observed in the rhizomes of Cyperus giganteus (Estelita \& Rodrigues 2007) and Fuirena umbellata Rottb. (Rodrigues \& Estelita 2009). According to Estelita \& Rodrigues (2007), the intercalary meristem (IM) is frequent in leaves and internodes of many monocots, scapes and pedicels. However, it shows higher activity at the scapes, allowing the elongation of the internodes (Fisher 1970). It is believed that the presence of the IM at the apical region of A. trigynum rhizome indicates the beginning of floral scape formation, that is, the beginning of the reproductive stage, as seen in other Cyperaceae (Estelita \& Rodrigues 2007).

The PTM is a lateral meristem characteristic of monocots (Rudall 1991); it has been described for many plants of this group, and it may occur in herbaceous (Krauss 1948; Sajo 1992) and rhizomatous species (Rudall 1984, 1991; Rodrigues \& Estelita 2004, 2009), and in more immature regions of monocots with secondary growth (Fisher \& Tomlinson 1972). In Cyperaceae, it was registered for the genera Scirpus L. and Fimbristylis Vahl. by Rudall (1991), and in the species Cyperus esculentus (Gifford \& Bayer 1995) and C. giganteus, C. rotundus, Fuirena umbellata Rottb., Hypolitrum schraderianum Ness, Bulbostylis paradoxa (Spreng.) Lindm. (Rodrigues \& Estelita 2009). However, the term PTM, despite being used by many authors, as mentioned above, is still questioned. Zimmermann \& Tomlinson (1968; 1970 ; 1974) refer to it as "meristematic cap", while Menezes et al. (2005) assume that the PTM is the endoderm and the pericycle at meristematic stage and do not use the term.

Regarding its function, the PTM in involved in the primary thickening of the stem, in the formation of adventitious roots, and is related to the vascular system (Cheadle 1937; Krauss 1948; DeMason 1979a; b, 1980; 1983; Stevenson \& Fisher 1980; DeMason \& Wilson 1984; Rudall 1991; Gifford \& Bayer 1995). In A. trigynum, as well as in other Cyperaceae species studied by Rodrigues \& Estelita (2002, 2009), the PTM is responsible for the inner cortex formation, whose innermost layer is distinguished at the endoderm by the formation of the pericycle and of the adventitious roots.

In the roots of $A$. trigynum, it is noted that the pericycle and the meristematic endoderm can be recognized while still very close to the promeristem. In this organ, the formation of the inner cortex by the meristematic endoderm is evident, as also observed by Seago \& Marsh (1989) in Typha glauca Godr. (Typhaceae), Seago et al. $(1999 \mathrm{a}, \mathrm{b})$ in Hydrocharis morus-ranae L. (Hydrocharitaceae), Seago et al. (2000) in Pontederia cordata L. (Pontederiaceae), Melode-Pinna \& Menezes (2003) in Richterago Kuntze (Asteraceae), Rodrigues \& Estelita (2004) in Cyperus giganteus.

According to Melo-de-Pinna \& Menezes (2003), at the roots of Richterago Kuntze, the meristematic endoderm experiences successive anticlinal and periclinal divisions to form the inner cortex, remaining as a meristematic layer until its complete differentiation, when the Casparian strip arises. This is a striking feature for recognition of the endoderm (Van Fleet 1961). In stems, many authors called it "endodermous layer" as they could not observe the Casparian strip (Tomlinson 1969; Gifford \& Bayer 1995). In the studied species, Casparian strips were not observed in the endoderm cells, neither on the roots nor on the rhizome; however, it can be identified by its morphological features. At the roots, initially in meristematic regions, the endoderm can be recognized by having meristematic activity. At posterior stages, the endoderm consists of radially elongated cells, morphologically distinguished from the other layers, such as in Actinocephalus species studied by Scatena et al. (2005). On A. trigynum rhizome, the endoderm can be recognized by having cell features that distinguish from the other cortical cells, such as cell shape and parietal thickening, such as observed in other Cyperaceae species (Eiten 1969; Estelita 1993; Chabbi et al. 2000; Arruda \& Neves 2005 and Prata et al. 2007).

In monocots, the endoderm may present four development stages, starting with the Casparian strip, followed by the deposition of suberin lamella, thickening of lignin and, lastly, deposition of phenolic compounds, as observed by Rodrigues \& Estelita (2004) in the roots of Cyperus giganteus. In the roots of $A$. trigynum, the endoderm cells remain with their thin walls, 
and the thickening occurs in the walls of the innermost cortical cells, which was also observed by Rodrigues \& Estelita (2004) in C. giganteus roots. In the rhizome of $A$. trigynum, the walls of the endoderm cells lignify at maturity, as well as the walls of the inner cortical cells, which also present deposition of phenolic compounds.

The hypodermis, observed on the roots and rhizomes of $A$. trigynum, is common in Cyperaceae species, and originates independently, from the fundamental meristem (Rodrigues \& Estelita 2002, 2004), as also observed by Seago \& Marsh (1989) in T. glauca. Attention is drawn to some species of Cyperaceae, in which the hypodermis may occur even at the leaves (Metcalfe 1971), such as in Cyperus corymbosus Rottb. and Remirea maritima Aubl. (Estelita 1993). The number of layers, thickening and composition of the hypodermal cells may vary (Seago \& Marsh 1989). The Casparian strip may occur on the outermost layer, which is called exodermis by authors such as Van Fleet (1950). In this species, no modifications on the walls of hypodermal cells were observed, as well as in H. morsus-ranae, observed by Seago et al. (1999). At the roots of A. trigynum, however, the outermost layer of the hypodermis showed different content in the early stages of differentiation, similar to the content of epidermal cells, indicating a possible participation of this layer in the process of mucilage synthesis. In roots of $T$. glauca (Seago \& Marsh 1989) and H. morsus-ranae (Seago et al. 1999a), the hypodermis, as well as the thickened inner cortical cells, sustains the aerenchyma, a function that can also be attributed to the hypodermis in the roots of $A$. trigynum, which justifies the use of the term.

The inner cortex of $A$. trigynum roots differentiates in lysigenous aerenchyma, as defined by Seago et al. (2005). However, these same authors classify the tangential lysigenous type for Cyperaceae, where the separation and collapse of the cells occur tangentially among the intact lines of cells. On the other hand, in A. trigynum, we can observe the formation of lysigenous-radial aerenchyma, where the separation and collapse of cells occur radially among the intact radial lines of cells. The aeriferous system of $A$. trigynum roots was also observed in other species from saline environments, such as Jaumea carnosa (Less.) Gray (Omer \& Moseley 1981) and R. maritima
(Estelita 1993). According to Cordazzo et al. (2006), aerenchyma is crucial in this environment, as it allows for gas exchange and maintains the aerobic environment, having the species occupy bigger areas during the rainy season, when competition with other perennial species with less capability to resist the floods diminishes.

The rhizome of $A$. trigynum shows a great quantity of starch grains. This characteristic is common in thickened rhizomes, and it is considered an adaptive strategy of plants from xeric environments (Braendle \& Crawford 1982).

The results obtained in this work show that the underground system of $A$. trigynum presents anatomical features that can be considered common to Cyperaceae species, such as the presence of a primary thickening meristem at the rhizome, meristematic endoderm, aerenchyma originated from the roots and presence of hypoderma in both organs. Other characteristics such as thickening and lignification of cells, high concentrations of starch grains and phenolic substances, large intercellular spaces and mucilage at the roots, can be regarded as potential strategies to adapt to dunes environment.

\section{Acknowledgments}

The authors thank the Graduate Program on Plant Biology of Universidade Federal de Santa Catarina; Capes for granting a Graduate student to the first author, and to CNPq (481623/2007-8) for the financial support.

\section{References}

Appezzato-da-Glória, B. 2003. Morfologia de sistemas subterrâneos: histórico e evolução do conhecimento no Brasil. A.S. Pinto, Ribeirão Preto. 80p.

Alonso, A.A. \& Moraes-Dallaqua, M.A. 2004. Morfoanatomia do sistema caulinar de Canna edulis Kerr-Gawler (Cannaceae). Revista Brasileira de Botânica 27: 229-239.

Alves, M.; Araújo, A.C.; Prata, A.P.; Vitta, F.; Hefler, S.; Trevisan, R.; Gil, A.S.B.; Martins, S. \& Thomas, W. 2009. Diversity of Cyperaceae in Brazil. Rodriguésia 60: 771-782.

Arruda, R.C.O. \& Neves, L.J. 2005. Anatomia foliar de Trilepis lhotzkiana Ness e Trilepis ciliatifolia T. Koyama (Cyperaceae) Juss. Acta Botanica Brasilica 19: 889-897.

Beckel, D.K. 1956. Cortical disintegration in the roots of Bouteloua gracilis (H.B.K.) Lag. New Phytologist 55: 183-190. 
Bell, A.D. 1991. Plant form: an illustrated guide to flowering plant morphology. University Press, Oxford, 341p.

Beltrame, A.V.; Bunn, D.A.; Chaves, A.P.N. \& Voges, M.S. 2006. Conhecendo o Parque Municipal das Dunas da Lagoa da Conceição. Editora UFSC, Florianópolis. 31p.

Braendle, R \& Crawford, R.M.M. 1982. Rhizome anoxia tolerance and habitat specialization in wetland plants. In: Crawford, R.M.M. (ed.). Plant life in aquatic and amphibious habitats. Blackwell Scientific Publications, Oxford. Pp. 397-411.

Bukatsch, F. 1972. Bemerkungen zur Doppelfärbung Astrablau-Safranin. Mikrokosmos 61: 255.

CECCA (Centro de Estudos Cultura e Cidadania). 1996. Uma cidade numa ilha: relatório sobre os problemas sócio-ambientais da Ilha de Santa Catarina. Insula, Florianópolis, 247p.

Clarck, L.H. \& Harris, W.H. 1981. Observations on the root anatomy of rice (Oryza sativa L.). American Journal of Botany 68: 154-161.

Chabbi, A.; Mckee, K.L. \& Mendelssohn, I.A. 2000. Fate of oxygen losses from Typha domingensis (Typhaceae) and Cladium jamaicense (Cyperaceae) and consequences for root metabolism. American Journal of Botany 87: 1081-1090.

Cheadle, V.I. 1937. Secondary growth by means of a thickening ring in certain monocotyledons. Botanical Gazette 98: 535-555.

Cordazzo, C.V.; Paiva, J.B. \& Seeliger, U. 2006. Guia ilustrado: plantas das dunas da costa sudoeste Atlântica. USEB, Pelotas. 107p.

Costa, C.S.B.; Seeliger, U. \& Cordazzo, C.V. 1988. Dinâmica populacional e distribuição horizontal de Androtrichum trigynum (Spreng.) Pfeiffer (Cyperaceae) em brejos e dunas costeiras do Rio Grande do Sul, Brasil. Acta Limnologica Brasiliensia 11: 813-842.

DeMason, D.A. 1979a. Histochemistry of the primary thickening meristem in the vegetative stem of Allium cepa L. American Journal of Botany 66: 347-350.

DeMason, D.A. 1979b. Function and development of primary thickening meristem in the monocotyledon, Allium cepa L. The Botanical Gazette 140: 51-66.

DeMason, D.A. 1980. Localization of cell division activity in the primary thickening meristem in Allium cepa L. American Journal of Botany 67: 393-399.

DeMason, D.A. 1983. The primary thickening meristem: Definition and function in monocotyledons. American Journal of Botany 70: 955-962.

DeMason, D.A. \& Wilson, M.A. 1984. The continuity of primary and secondary growth in Cordyline terminalis (Agavaceae). Canadian Journal of Botany 63: 1907-1913.
Dickison, W.C. 2000. Integrative plant anatomy. Academic Press, San Diego. 533p.

Drew, M.C.; He, C. \& Morgan, P.W. 2000. Programmed cell death and aerenchyma formation in roots. Trends in Plant Science 5: 123-127.

Eiten, L.T. 1969. The vegetative anatomy of Eleocharis interstincta (Vahl) Roem. \& Schult. Arquivos de Botânica do Estado de São Paulo 4: 187-228.

Estelita, M.E.M. 1993. Anatomia dos órgãos vegetativos de Remirea maritima Aubl. (Cyperaceae). Naturalia 18: 123-134.

Estelita, M.E.M. \& Rodigues, A.C. 2007. Subsídios estruturais à caracterização do sistema caulinar em Cyperaceae. Revista Brasileira de Botânica 30: 401-409.

Fahn, A. \& Cutler, D.F. 1992. Xerophytes. Encyclopedia of plant anatomy. Vol. XIII.3. Gebrüder Borntraeger, Berlin. 176p.

Feder, N. \& O’Brien, T.P. 1968. Plant microtechnique: some principles and new methods. American Journal of Botany 55: 123-142.

Fisher, J.B. 1970. Development of the intercalary meristem of Cyperus alternifolius. American Journal of Botany 57: 691-703.

Fisher, J.N. \& Tomlinson, P.B. 1972. Morphological studies in Cordyline (Agavaceae). II. Vegetative morphology of Cordyline terminalis. Journal of the Arnold Arboretum 53: 113-127.

Font Quer, P., 1982. Diccionario de botánica. Labor, Barcelona. 1244p.

Gifford, E.M. \& Bayer, D.E. 1995. Development anatomy of Cyperus esculentus (yellow nutsedge). International Journal of Plant Sciences 156: 622629.

Govindarajalu, E. 1974. The systematic anatomy of south Indian Cyperaceae: Cyperus L. subgen. Juncellus, Cyperus subgen. Mariscus and Lipocarpha R. Br. Botanical Journal of the Linnean Society 68: 235-266.

Heimsch, C. 1960. A new aspect of cortical development in roots. American Journal of Botany 47: 195-201.

Herrmann, M.L.P. 1989. Aspectos ambientais da porção central da Ilha de Santa Catarina. Dissertação de Mestrado. Universidade Federal de Santa Catarina, Florianópolis. 228p.

Johansen, D.A. 1940. Plant microtechnique. McGrawWill, New York. 523p.

Kadej, F. 1963. Interpretation of the pattern of the cell arrangement in the root apical meristem of Cyperus gracilis L. var. alternifolius. Acta Societatis Botanicorum Poloniae 32: 295-301.

Kraus, J.E. \& Arduin, M. 1997. Manual básico de métodos em morfologia vegetal. Universidade Rural, Seropédica. 198p. 
Krauss, B.H. 1948. Anatomy of the vegetative organs of the pineapple, Ananas comosus (L.) Merr. I. Introduction, organography, the stem, and the lateral branch or axillary buds. Botanical Gazette 110: 159-217.

Kukkonen, I. 1967. Vegetative anatomy of Uncinia (Cyperaceae). Annals of Botany 31: 523-544.

Martins, A.R. \& Appezzato-da-Glória, B. 2006. Morfoanatomia dos órgãos vegetativos de Smilax polyantha Griseb. (Smilacaceae). Revista Brasileira de Botânica 29: 555-567.

Mauseth, J.D. 1988. Plant anatomy. BenjaminCummings, California. 560p.

Melo-de-Pinna, G.F.A. \& Menezes, N.L. 2002. Vegetative organ anatomy of Ianthopappus Roque \& D.J.N. Hind (Asteraceae-Mutisieae). Revista Brasileira de Botânica 25: 505-514.

Melo-de-Pinna, G.F.A. \& Menezes, N.L. 2003. Meristematic endodermis and secretory structures in adventitious roots of Richterago Kuntze (MutisieaeAsteraceae). Revista Brasileira de Botânica 26: $1-10$.

Menezes, N.L.; Silva, D.C.; Arruda, R.C.O.; Melo-dePinna, G.F.; Cardoso, V.A.; Castro, N.M.; Scatena, V.L. \& Scremin-Dias, E. 2005. Meristematic activity of the endodermis and the pericycle in the primary thickening in monocotyledons: considerations on the "PTM". Anais da Academia Brasileira de Ciências 77: 259-274.

Metcalfe, C.R. 1971. Cyperaceae. Vol. 5. Clarendon Press, Oxford. 596p.

O’Brien, T.P.; Fedder, N. Mccully, M. 1965. Polychromatic staining of plant cell walls by toluidine blue. Protoplasma 59: 368-373.

Omer, L.S. \& Moseley, Jr. M.F. 1981. The vegetative anatomy of Jaumea carnosa (Less.) Gray (Asteraceae) a salt marsh species. American Journal of Botany 68: 312-319.

Prata, A.P.; Menezes, N.L.; Mazzoni-Viveiros, S.C.; Wanderley, M.G.L. \& Thomas, W.W. 2007. Anatomia do escapo e rizoma de espécies brasileiras de Bulbostylis Kunth (Cyperaceae). Revista Brasileira de Botânica 30: 245-256.

Rodrigues, A.C. \& Estelita, M.E.M. 2002. Primary and secondary development of Cyperus giganteus Vahl rhizome (Cyperaceae). Revista Brasileira de Botânica 25: 251-258.

Rodrigues, A.C. \& Estelita, M.E.M. 2004. Anatomia da raiz de Cyperus giganteus Vahl (Cyperaceae) em desenvolvimento. Revista Brasileira de Botânica 27: 629-638.

Rodrigues, A.C. \& Estelita, M.E.M. 2009. Morphoanatomy of the stem in some Cyperaceae. Acta Botanica Brasilica 23: 889-901.
Rudall, P. 1984. Taxonomic and evolutionary implications of rhizome structure and secondary thickening in Iridaceae. Botanical Gazette 145: 524-534.

Rudall, P. 1991. Lateral meristems and stem thickening growth in monocotyledons. The Botanical Review 57: 150-163.

Sajo, M.G. 1992. Organização vascular do caule em Xyris L. (Xyridaceae). Boletim de Botânica da Universidade de São Paulo 13: 49-66.

Sass, J.E. 1951. Botanical microtechnique. 2ed. Iowa State College Press, Iowa. 228p.

Scatena, V.L.; Oriani, A. \& Sano, P.T. 2005. Anatomia de raízes de Actinocephalus (Koern.) Sano (Eriocaulaceae). Acta Botanica Brasilica 19: 835841.

Seago, J.L. \& Marsh, L.C. 1989. Adventitious root development in Typha glauca, with emphasis on the cortex. American Journal of Botany 76: 909-923.

Seago, J.L.; Marsh, L.C.; Stevens, K.J.; Souku, A; Votrubová, O. \& Enstone, D.E. 2005. A reexamination of the root cortex in wetland flowering plants with respect to aerenchyma. Annals of Botany 96: 565-579.

Seago, J.L.; Peterson, Carol A. \& Enstone, D.E. 1999a. Cortical ontogeny in roots of the aquatic plant, Hydrocharis morsus-ranae L. Canadian Journal of Botany 77: 113-121.

Seago, J.L.; Peterson, C.A.; Enstone, D.E.; Scholey, C.A. 1999b. Development of the endodermis and hypodermis of Typha glauca Godr. and Typha angustifolia L. roots. Canadian Journal of Botany 77: 122-134.

Seago, J.L.; Peterson, C.A. \& Enstone, D.E. 2000. Cortical development in roots of the aquatic plant Pontederia cordata (Pontederiaceae). American Journal of Botany 87: 1116-1127.

Sharma, O.P. \& Mehra P.N. 1972. Systematic anatomy of Fimbristylis Vahl (Cyperaceae). Botanical Gazette 133: 87-95.

Stevenson, D.W. \& Fisher, J.B. 1980. The developmental relationship between primary and secondary thickening growth in Cordyline (Agavaceae). The Botanical Gazette 141: 264-268.

Tomlinson, P.B. 1969. Commelinales-Zingiberales. In: Metcalfe, C.R. (ed.). Anatomy of the monocotyledons. Vol. 3. Clarendon Press, Oxford. Pp. 295-421.

Van Fleet, D.S. 1950. A comparison of histochemical and anatomical characteristics of the hypodermis with the endodermis in vascular plants. American Journal of Botany 37: 721-724.

Van Fleet, D.S. 1961. Histochemistry and function of the endodermis. The Botanical Review 27: 165-220.

Zimmermann, M.H. \& Tomlinson, P.B. 1968. Vascular construction and development in the aerial stem of 
Prionium (Juncaceaae). American Journal of Botany 55: 1100-1109.

Zimmermann, M.H. \& Tomlinson, P.B. 1970. The vascular system in the axis of Dracaena fragans (Agavaceae). II. Distribution and development of secondary vascular tissue. Journal of the Arnold Arboretum 51: 478-491.

Zimmermann, M.H. \& Tomlinson, P.B. 1974. Vascular patterns in palm stems: Variations of the Rhapis principle. Journal of the Arnold Arboretum 55: 402-424.
Williams, B.C. 1947. The structure of the meristematic root tip and origin of the primary tissues in the roots of vascular plants. American Journal of Botany 34: 455-462.

Wills, G.D. 1987. Description of purple and yellow nutsedge. Weed Technology 1: 2-9.

Wills, G.D. \& Briscoe, G.A. 1970. Anatomy of purple nutsedge. Weed Science 18: 631-635.

Wills, G.D.; Hoagland, R.E. \& Paul, R.N. 1980. Anatomy of yellow nutsedge (Cyperus esculentus). Weed Science 28: 432-437. 